UDC 338.2:[330.15:502.171](042.5) JEL: O12, O13, 044

\author{
Natalya Andryeyeva \\ Doctor of Economics, Profesor, \\ Chief Researcher, \\ Institute of Market Problems and \\ Economic\&Ecological Research NAS \\ of Ukraine, \\ Odessa, Ukraine \\ E-mail: andreevann@ukr.net \\ orcid.org/0000-0002-9960-559X
}

\author{
Hanna Tiutiunnyk \\ Ph.D., Researcher, \\ Institute of Market Problems and \\ Economic\&Ecological Research NAS \\ of Ukraine, \\ Odessa, Ukraine \\ E-mail: ecoregnaturres@ukr.net \\ orcid.org/0000-0003-4864-6129
}

Received: May, 2020 Accepted: August, 2020

DOI:10.31520/2616-7107/2020.4.3-3

(C) Economics. Ecology. Socium, 2020 CC BY-NC 4.0 license

\section{ASSESSMENT OF INNOVATION AND INVESTMENT POTENTIALS AS A STRATEGIC BASIS FOR IDENTIFICATION OF SMART SPECIALIZATION OF REGIONS OF UKRAINE}

Introduction. The key role in maintaining the competitiveness of economic systems belongs to the innovative specialization of economic activity, which diversifies economic activity. The existing methodological approaches to determining the strategic priorities of Smart Specialization of a particular region do not fully take into account the assessment of innovation and investment potential, taking into account the environmental component of sustainable development.

Aim and tasks. The purpose of the proposed study is the formation of scientific approaches to assessing innovation and investment potential in the context of the formation of strategic regional environmental policy in the context of the methodology of Smart Specialization.

Results. The article substantiates the methodological provisions for combining the methodology of Quintuple helix, Smartspecialization and Sustainable Development Goals. The institutional essence of investment and innovation policy of nature management at the regional level as a modern model of Quintuple helix is determined. An assessment of the innovation potential of the regions as a component of investment and innovation policy of nature management. The dynamics of implementation of environmental innovations by enterprises of Ukraine, the concentration of higher education institutions by regions, in particular, subordinate government agencies are analyzed. The number of students, specialists in higher education institutions majoring in natural sciences, employment in the field of nature management has been determined. The strengthening of the ecological component in the scientific and educational spheres is established for the further implement the borrowed knowledge in the formation of investment and innovation policy of nature management of individual regions. The natural resource potential of the country in terms of regions according to the statistical database is studied.

Conclusions. The presented research proposes the author's vision, which allows not only to outline the dominants of Smart Specialization of кegions in order to determine the strategic priorities of investment and innovation policy of the national sphere of nature, but also to explore the uniqueness of regions based on scientific and technical potential. Implementation of the Smart Specialization Strategy, which will combine the methodology of Quintuple helix and Smart Specialization will provide an opportunity to determine the approach to the formation and implementation of state regional policy. A methodological approach to determining the dominants of investment and innovation regional environmental policy has been developed, taking into account the methodology of "Smart Specialization" and in the context of existing European experience.

Keywords: smart specialization, sustainable development, innovation, investment potentials. 


\section{УДК 338.2:[330.15:502.171](042.5) JEL: O12, O13, 044}

\section{ОЦНКА ІННОВАЦІЙНОГО ТА ІНВЕСТИЦЙНОГО ПОТЕНЦІАЛІВ ЯК СТРАТЕГІЧНОГО БАЗИСУ ІДЕНТИФІКАЦІЇ SМАRТ-СПЕЦІАЛІЗАЦЇ̈ РЕГІОНІВ УКРАЇНИ}

\author{
Наталя Андрєсва \\ д.е.н., проф., голов. н.с., \\ Інститут проблем ринку та \\ економіко-екологічних \\ досліджень НАН України, \\ Одеса, Україна \\ E-mail: andreevann@ukr.net \\ orcid.org/0000-0002-9960-559X

\section{Ганна Тютюнник} \\ к.е.н., н.c., \\ Інститут проблем ринку та \\ економіко-екологічних досліджень \\ НАН України, \\ Одеса, Україна \\ E-mail: ecoregnaturres@ukr.net \\ orcid.org/0000-0003-4864-6129
}

Отримано: Травень, 2020

Прийнято: Серпень, 2020

DOI:10.31520/2616-7107/2020.4.3-3

(C) Економіка. Екологія. Соціум, 2020 CC BY-NC 4.0 ліцензія
Вступ. Ключова роль у підтримці конкурентоспроможності економічних систем належить інноваційній спеціалізації господарської діяльності, яка урізноманітнює економічну діяльність. Існуючі методологічні підходи до визначення стратегічних пріоритетів розумної спеціалізації певного регіону не враховують повною мірою оцінку інноваційного та інвестиційного потенціалу, враховуючи екологічну складову сталого розвитку.

Мета і завдання. Метою запропонованого дослідження $\epsilon$ формування наукових підходів до оцінки інноваційного та інвестиційного потенціалу в контексті формування стратегічної регіональної екологічної політики в контексті методології розумної спеціалізації.

Результати. У статті обгрунтовано методичні положення щодо поєднання методології Quintuple helix, Smart-спеціалізації та Цілей сталого розвитку. Визначено інституційну сутність інвестиційно-інноваційної політики природокористування на регіональному рівні як сучасної моделі Quintuple helix. Проведено оцінку інноваційного потенціалу регіонів як складової інвестиційно-інноваційної політики природокористування. Проаналізовано динаміку впровадження природоохоронних інновацій підприємствами України, концентрацію закладів вищої освіти в розрізі регіонів, зокрема підпорядкованим державним органам управління. Визначено кількість студентів, фахівців у закладах вищої освіти за спеціальністю природничі науки, зайнятість населення у сфері природокористування. Встановлено посилення екологічної складової у науковій та освітній сферах 3 метою подальшої імплементації запозичених знань при формування інвестиційно-інноваційної політики природокористування окремих регіонів. Досліджено природно-ресурсний потенціал країни в розрізі регіонів за статистичною базою даних.

Висновки. Представлене дослідження пропонує авторське бачення, яке дозволяє не лише окреслити домінанти розумної спеціалізації регіонів 3 метою визначення стратегічних пріоритетів інвестиційно-інноваційної політики національної сфери природи, а й дослідити унікальність регіонів на основі науково-технічний потенціал. Реалізація Стратегії інтелектуальної спеціалізації, яка поєднає методологію Quintuple helix та Smart Specialization, надасть можливість визначити підхід до формування та реалізації державної регіональної політики. Розроблено методичний підхід щодо визначення домінант інвестиційно-інноваційної регіональної політики природокористування 3 урахуванням методології «Smart Specialization» та в контексті існуючого європейського досвіду.

Ключові слова: smart specialization, сталий розвиток, інновації, інвестиційний потенціал. 
Introduction. The key role in maintaining the competitiveness of economic systems belongs to the innovative specialization of economic activity, which diversifies economic activity. The lack of a clear innovation-oriented specialization of production and the trend towards the concentration of innovation-oriented services indicates the necessary development of relevant clusters [1, p. 240].

Unlike traditional ones, they should include so-called institutions of knowledge and attracting talent to the place of concentration of resources and financing of their efficient and rational use. In 2018, the Resolution of the Cabinet of Ministers of November 14, 2018 № 959 came into force in Ukraine, according to which all regions within the regional development strategy must determine at least one strategic goal based on the European methodology of Smart Specialization.

The Ministry of Economic Development, Trade and Agriculture planned to allocate UAH 6.75 billion in 2021-2023 for Smart Specialization of Regions. Strategic guidelines for regional development for 2021-2027 aimed at solving the tasks of the previous period, which was characterized by the financing of projects aimed at the development of funds, ignoring the creation of new jobs and increasing budget revenues [2].

Requirements for Smart Specialization are approved at the state level by the relevant resolutions of the Cabinet of Ministers of Ukraine "On approval of the Procedure for developing the State Strategy for Regional Development of Ukraine and action plan for its implementation, as well as monitoring and evaluating the effectiveness of these Strategy and Action Plan".

The EU's "Smart Specialization" platform provides both informational and expert, as well as financial support using the resources of the European Structural and Investment Funds.
The pilot regions will receive individual support from the European Union to quickly remove investment barriers and innovate. In addition, we are talking about the automation of production, the transition to alternative energy sources - depending on the Smart Specialization of a particular region. Today, only three regions of Ukraine have been selected as participants in the EU's Smart Specialization platform: Odesa, Kharkiv and Zaporizhia [3]. But according to the authors of the study, the existing methodological approaches to determining the strategic priorities of Smart Specialization of a particular region do not fully take into account the assessment of innovation and investment potential, taking into account the environmental component of sustainable development.

Literature review. In science and practice, the methodology of Smart Specialization is actively considered in the formation of regional policy. This is the methodology used in the European Union to substantiate the priorities of the country's economic development. The Intelligent / Smart Specialization Platform (S3) was established by the European Commission in June 2011 at the IPTS2 Joint Research Center in Seville, Spain. "Intelligent Specialization" (S3) is designed to assist EU Member States and regions in developing, implementing research and innovation strategies for smart Specialization (RIS3).

The Smart Specialization concept focuses on the development and implementation of innovative strategies that take into account regional characteristics, namely: economic structure, existing areas of excellence, clusters, research and development, research institutions, expansion of interregional and international networks of scientific and technical cooperation [4]. A review of the literature on the disclosure of the essence of the methodology used in the coverage of Smart Specialization is given in Table 1 . 
Table 1. Review of the literature on the disclosure of the essence of the methodology used in the coverage of Smart Specialization

\begin{tabular}{|l|l|}
\hline \multicolumn{1}{|c|}{ Author } & \multicolumn{1}{|c|}{ The essence of the methodology } \\
\hline $\begin{array}{l}\text { Ortega A.R., McCann, P., } \\
\text { Perianez-Forte, I., Cervantes, M., } \\
\text { Larosse, J., \& Sanchez, L. [6] }\end{array}$ & $\begin{array}{l}\text { The use of methods for forecasting and diagnosing regional features to identify } \\
\text { new activities, possible synergies and complementarities that may arise in the } \\
\text { regional context. }\end{array}$ \\
\hline $\begin{array}{l}\text { Sugimoto, C.R., Robinson- } \\
\text { Garcia, N. and Costas, R. [7] }\end{array}$ & $\begin{array}{l}\text { Use of scientific publications on conducting diachronic network analysis to } \\
\text { identify patterns of mobility among the location of the region. }\end{array}$ \\
\hline $\begin{array}{l}\text { Bakhshi, H. and Mateos-Garcia, } \\
\text { J. [8] }\end{array}$ & $\begin{array}{l}\text { Use of unstructured data to identify areas of technological and economic } \\
\text { activity in a more accurate way by methods of information analysis }\end{array}$ \\
\hline $\begin{array}{l}\text { Internet resources, public } \\
\text { relations }\end{array}$ & $\begin{array}{l}\text { Use public feedback and increase accountability of all stakeholders in the RIS3 } \\
\text { process. Use of data and technologies of social media, online tools. }\end{array}$ \\
\hline Delaney, K. and Osborne, L. [9] & $\begin{array}{l}\text { Involvement of RIS3 beneficiaries and users, public consultations, expert } \\
\text { recommendations, submission through web tools. }\end{array}$ \\
\hline
\end{tabular}

Previously unsettled problem constituent. Smart Specialization in the author's sense should determine the relationship of sectors of the economy through the innovation and natural resource component, which creates stability between local economic entities. It is a combination of policy concepts, sectoral and cross-sectoral use of innovation and technology. Smart Specialization aims to: 1) search for dominant clusters of economic growth, areas with a small number of owners for simplified cooperation, 2) search and reorganization of various specializations, 3) understanding the distribution of risks [5].

This methodology is not just about developing new specializations in regions that have the potential to grow through local opportunities. It (so-called "Smart Specialization") is also the development of new specializations in regions that are unique in the world, more complex, that improve the local economy, in particular in the field of environmental management. The complexity of knowledge means the degree of sophistication and the number of opportunities required to develop a new technology. Today, the regional policy of European countries is implemented together with the state innovation policy and policy to promote entrepreneurship, which creates conditions for economic development of regions, effective use of existing potential ${ }^{1}$.

\footnotetext{
1 On approval of the State Strategy for Regional Development until 2020: Resolution of the Cabinet of Ministers of Ukraine of August 6, 2014 № 385. Official Gazette of Ukraine of 09.09.2014, № 70, p. 23, Article 1966, act code 73740/2014.
}

Main purpose of the article. The purpose of the proposed study is the formation of scientific approaches to assessing innovation and investment potential in the context of the formation of strategic regional environmental policy in the context of the methodology of Smart Specialization.

Results and discussions. Smart Specialization Strategy means a national or regional innovation strategy that prioritizes competitive advantage by developing and adapting its own research and innovation capabilities to business needs in order to consistently respond to new opportunities and market changes, while avoiding duplication and fragmentation; the Smart Specialization strategy may take the form of or be part of a national or regional research and innovation policy (paragraph 3, Article 2).

The Strategy should be developed taking into account the changes that have taken place in the development of regions of the state in recent years, characterized by the formation of a long period of inefficient system of regional development management and non-transparent mechanism of financial support for regional development. the mechanism of relations at the level of "state region" and the regions among themselves, the imperfection of the system of territorial organization of power and the delay in reforming local self-government and administrative-territorial organization. The priorities of the state regional policy are:

- increasing the competitiveness of regions and strengthening their resource potential to increase the level of competitiveness of regions; 
- territorial socio-economic integration and spatial development;

- effective public administration in the field of regional development.

Smart Specialization of regions in the modern dimension should include:

- digital information and mobile technologies;

- space for rapprochement and cooperation of communities, stakeholders, business, universities;

- platforms for the development of innovations in the field of nature management;

- corporate innovation center;

- natural resources to create RIS3;

- building institutional capacity in the context of the development of the 4helix spiral with subsequent transformation into 5 helix.

Fragmentary financial and administrative support for enterprises or industries, sometimes in individual regions, and government subsidies have been characterized by their inefficiency in the long run.
The modern approach requires the identification of unrealized economic and human potential and a qualitative assessment of consumer needs to meet them in an innovative way $[10$, p. 3].

Expert assessment of Smart Specialization of Regions is an overview of the location of the region and its socioeconomic and environmental potential. Areas to be evaluated include stakeholder engagement, RIS3 analytical work, shared vision, priorities, action plan, external orientation, synergies between policy and funding sources, and a convergence (monitoring) and monitoring system. [11] (fig. 1).

In the process of Smart Specialization, zoning takes place by combining areas in science and education, areas of industrial production and areas not focused on science and technology, within which there are different subcategories. These categories reflect the main areas of activity and the relationship of knowledge, innovation and regional characteristics in the EU.

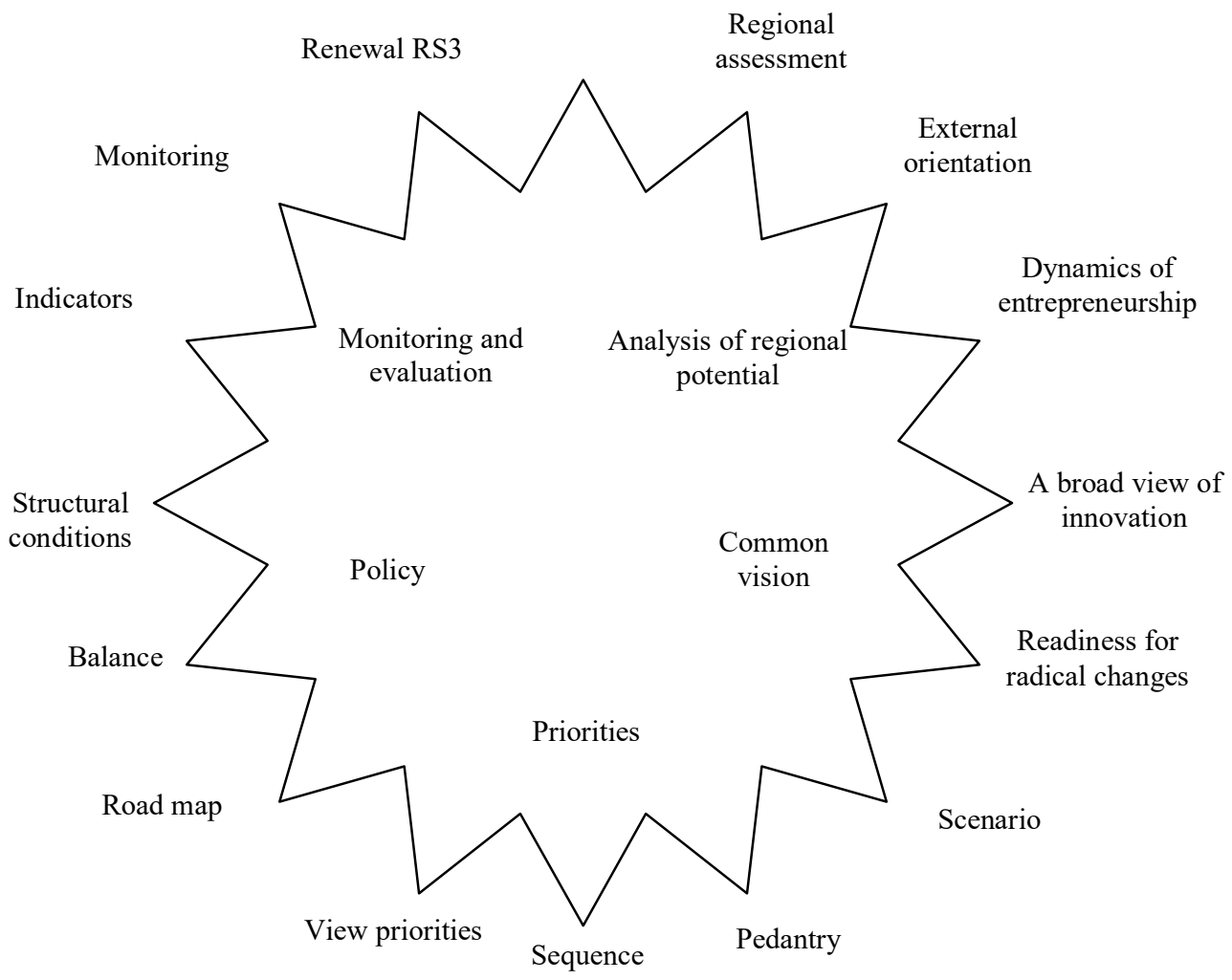

Fig. 1. RIS3 assessment scheme based on identification measures Smart Specialization Regions Source: formed on the basis of [12]. 
In the process of Smart Specialization, zoning takes place by combining areas in science and education, areas of industrial production and areas not focused on science and technology, within which there are different subcategories. These categories reflect the main activities and interrelationships of knowledge, innovation and regional specificities in the EU.

Today Ukraine is an industrial-agrarian country, but some experts emphasize the return of our state to the agrarian-industrial model. In this context, the provision of rational nature management in the regional policy will be of special importance. Ukrainian agricultural exports - grain, oil, livestock and poultry products, goods of processing industries - are almost international. Accordingly, for further effective development and taking into account the rich natural resource potential of our country, it is necessary to identify areas with a specific focus on nature management.
According to domestic analysts, Ukraine's weaknesses in terms of innovation in international indices are: "environmental sustainability", institutions, protection of intellectual property rights, the state of cluster development, development of broadband Internet, innovation environment. In Ukraine, systemic obstacles that hinder the formation of "smart specialization" are associated with the centralized and universal nature of strategic planning of economic development, which does not take into account the conditions and needs of specific regions (Table. 2). Analysis of the financing of existing priority areas of innovation is carried out in Ukraine on the basis of the Law of Ukraine "On Priority Areas of Innovation in Ukraine", which defines seven strategic priority areas of innovation, and the Cabinet of Ministers of Ukraine dated 28.12.2016 №1056, which strategic priorities identified 41 medium-term priority areas of innovation at the national level [14].

Table 2. Dynamics of the rating of some countries according to the Innovation Efficiency Index for 2010 - 2018

\begin{tabular}{|l|c|c|c|c|c|c|c|}
\hline \multicolumn{1}{|c|}{ Country } & 2010 & 2012 & 2014 & 2015 & 2016 & 2017 & 2018 \\
\hline Ukraine & 54 & 14 & 14 & 15 & 12 & 11 & 5 \\
\hline Kazakhstan & 77 & 131 & 118 & 124 & 108 & 116 & 111 \\
\hline China & 14 & 1 & 2 & 6 & 7 & 3 & 3 \\
\hline USA & 63 & 70 & 57 & 33 & 25 & 21 & 22 \\
\hline Germany & 56 & 11 & 19 & 13 & 9 & 7 & 9 \\
\hline Poland & 85 & 80 & 76 & 93 & 66 & 48 & 42 \\
\hline India & 101 & 2 & 31 & 31 & 63 & 53 & 49 \\
\hline Japan & 18 & 88 & 88 & 78 & 65 & 49 & 44 \\
\hline Switzerland & 15 & 5 & 6 & 2 & 5 & 2 & 1 \\
\hline Luxembourg & 5 & 8 & 9 & 3 & 1 & 1 & 2 \\
\hline
\end{tabular}

Source: formed using [13]

The number of enterprises that have implemented environmental innovations is characterized by uniformity between regions, but the highest level is occupied by Rivne region, Vinnytsia and Poltava (Fig. 2). 


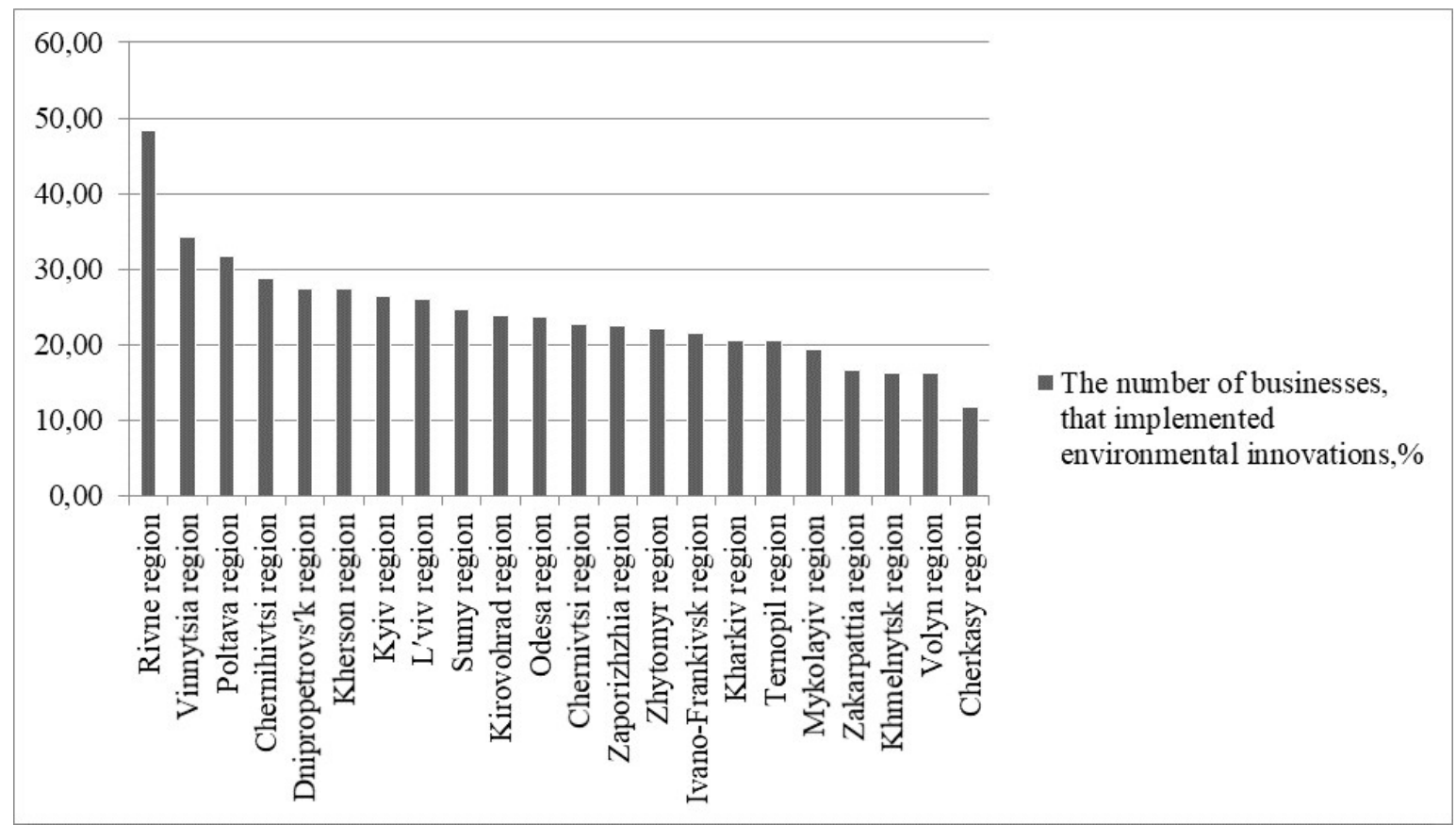

Fig. 2. Number of enterprises that have implemented environmental innovations, $\%$ Source: formed using [15].

Smart Specialization (S3) focuses on the role of universities and university research as a key driver of innovation and regional development. This is seen as providing the necessary cohort of skilled knowledgeable professionals who can conduct research, commercialize intellectual property and catalyze the adoption of research. In Ukraine, the largest number of higher education institutions is concentrated in Kharkiv, Dnipropetrovsk, Lviv and Odessa regions (Fig. 3, 4).

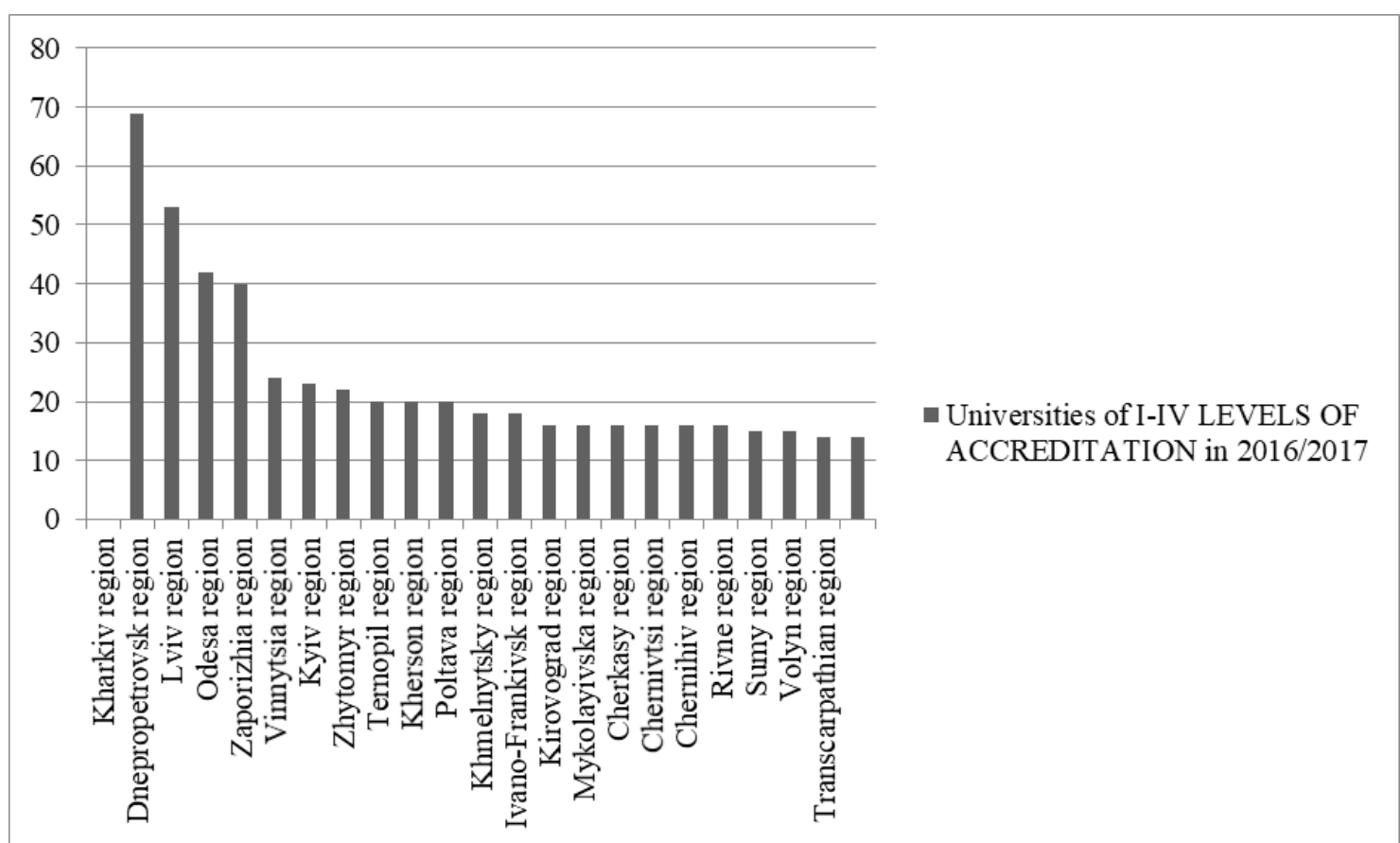

Fig. 3. Higher educational institutions of I-IV levels of accreditation in 2016/2017, units Source: formed on the basis of [16]. 
Most higher education institutions are subordinated to the Ministry of Education and Science of Ukraine. The Ministry of Agrarian Policy and Food of Ukraine and the State Agency of Forest Resources of Ukraine, which primarily train specialists in natural sciences, occupy the middle link in the ranking of universities by number in the country. The training of specialists in nature management among universities and colleges is more numerous in the agricultural sciences.

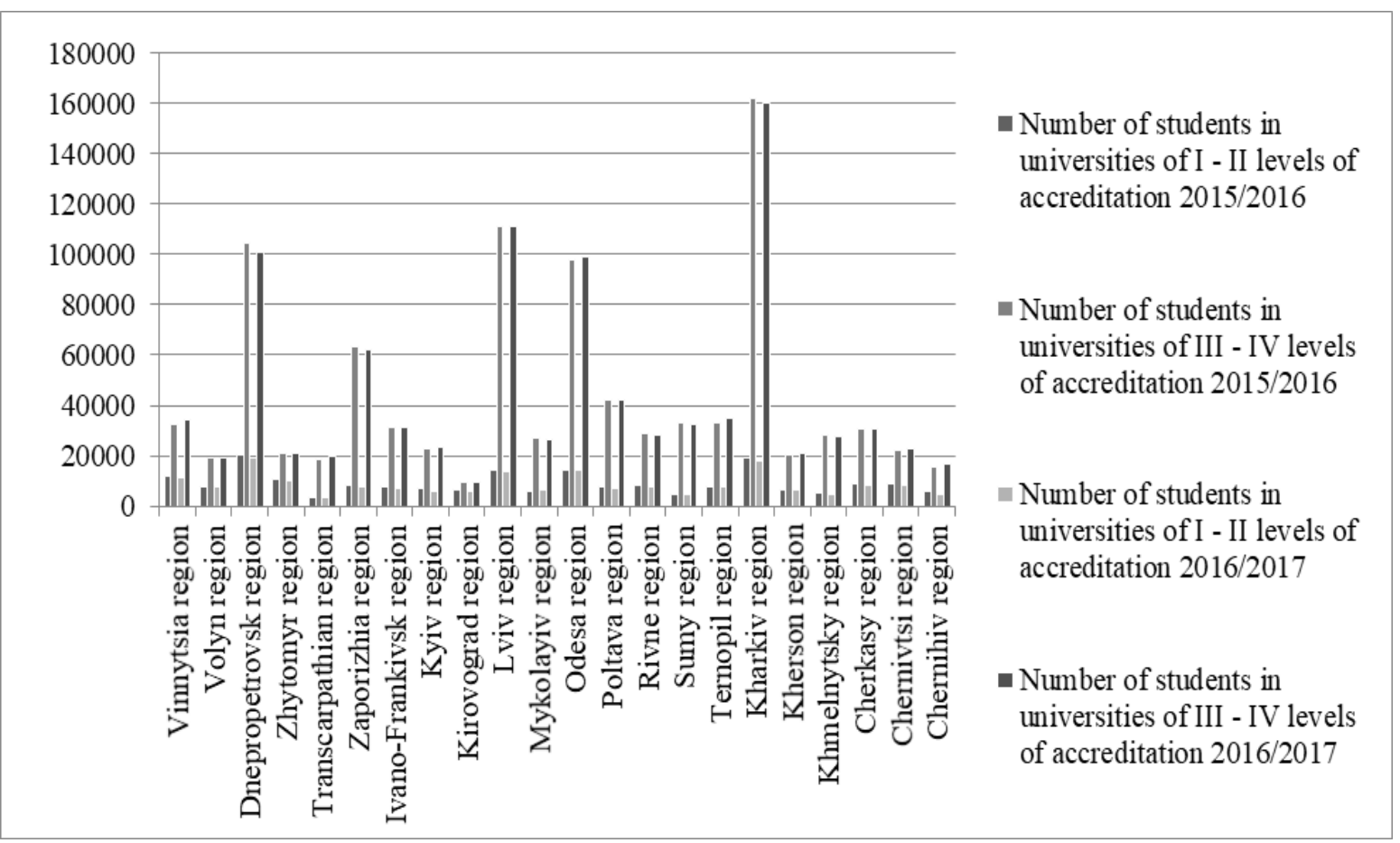

Fig. 4. Number of students at the beginning of the school year, pers.

Source: formed on the basis of [17].

Innovative literature tends to exaggerate the role and effectiveness of university-based research and development, focuses on knowledge creation rather than knowledge dissemination and exploitation, and gives priority to research universities over other types of educational institutions and opportunities. There is a lack of good strategic intelligence or forecasting models, and often a commitment within education, especially higher education, that it should not be too closely aligned with business and economics. Despite the average level of provision of the country with higher education institutions with the predominance of environmental sciences, employment in this area is characterized by negative dynamics in recent years (Fig. 5). 


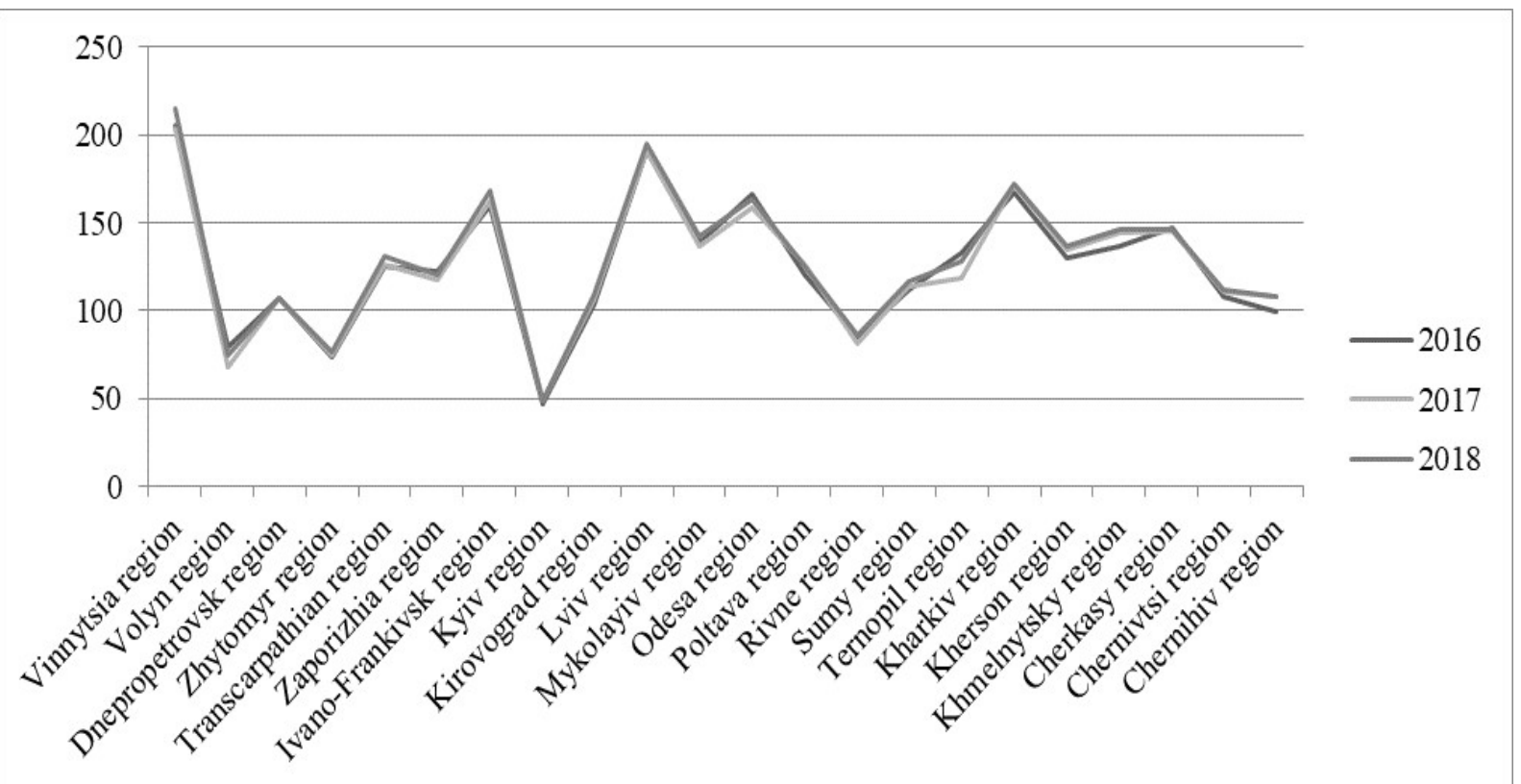

Fig. 5. Employment in the field of nature management for 2016-2018 in regions, including

Source: formed on the basis of [18]. agriculture, forestry and fisheries, pers.

Priorities are usually set by the institution based on the competencies of teachers / academics, interests and priorities, which are not always well aligned with the (changing) socio-economic context and do not change easily due to contractual issues. There are also no mechanisms through which the vision of the region can be discussed, agreed upon and implemented. In this context, it is very important to strengthen the environmental component in the scientific and educational spheres in order to further implement the borrowed knowledge in the formation of investment and innovation policy of nature in certain regions.

The business process will be different in each region according to the density of innovators and entrepreneurs in some regions and low population, small number of sectors and large dominant organizations, but with few external links - in others. According to the Procedure for evaluation of regional development projects that can be implemented from the state budget received from the European Union [19], the expected result is to increase the competitiveness of regions through regional and local economies on the basis of effective use of existing potential, existing competitive advantages, formation of a favorable investment environment, modernization of the real sector of the economy, growth of export potential, creation of conditions for intensification of innovation processes taking into account the principles of Smart Specialization. Preservation and restoration of natural areas have found their place in the areas of rural and tourist development of the regions.

Analyzing the information data of the Gross Regional Product and the scheme of growth dynamics of the general indicator, which characterizes the level of economic development of the region, we can begin to identify priorities of investment and innovation regional environmental policy taking into account the methodology "Smart Specialization" (Fig. 6).

Relevant regions are Dnipropetrovsk UAH 313,830 million. in 2017, Kharkiv UAH 187,454 million. and Kyiv - UAH 157043 million. The indicators of Zaporizhia, Lviv and Poltava regions are quite close. 


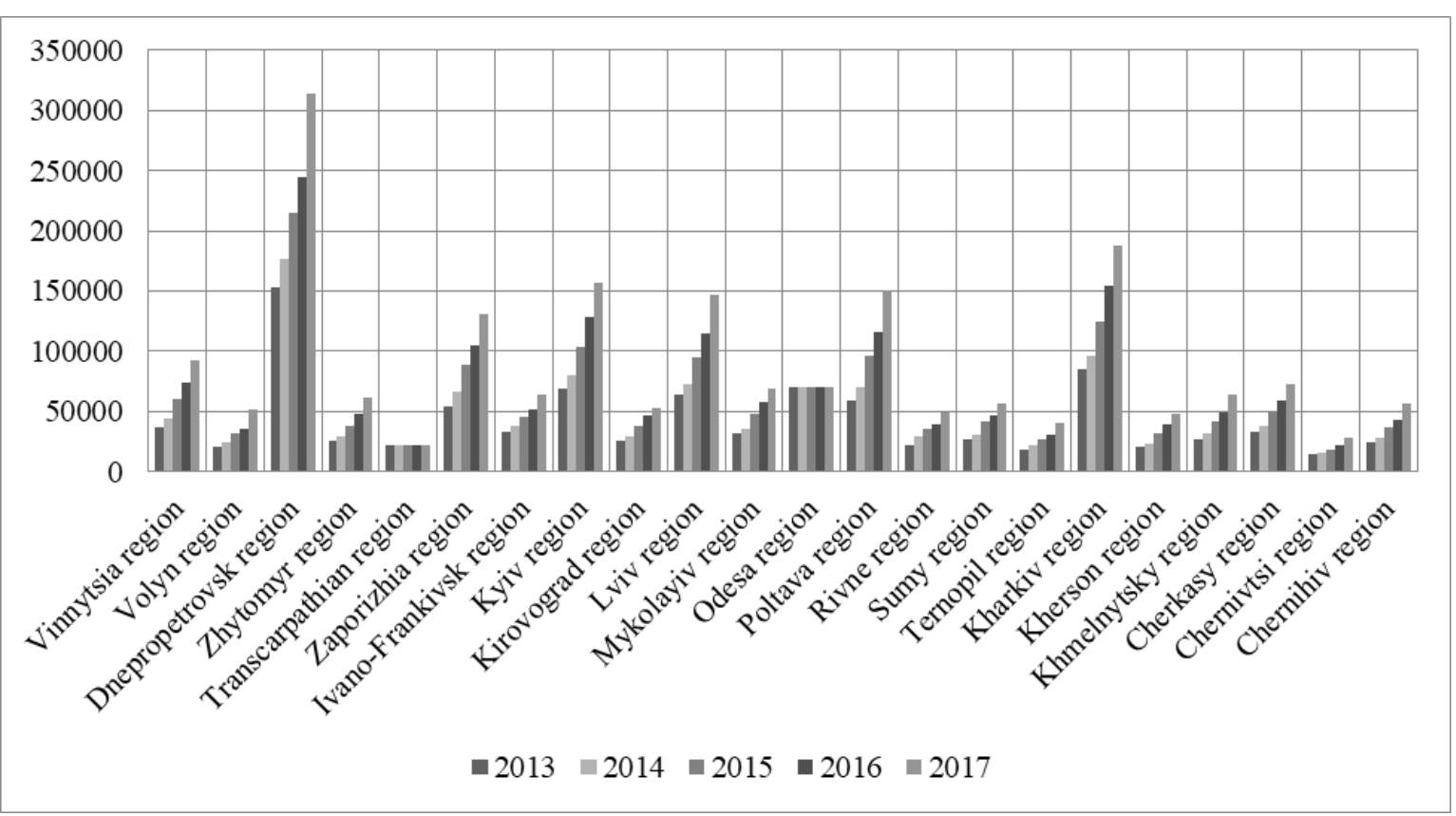

Fig. 6. Dynamics of gross regional product in actual prices for 2013-2017, UAH million Source: formed using [20].

Issues of financing small and medium enterprises, cluster development can be addressed with the participation of regional authorities, which should provide a comprehensive approach to meeting the needs of small and medium enterprises, covering all stages of their creation and development in research and innovation projects. Such forms can be: grants, loans, and in some cases guarantees. In addition, promoting participation in EU-funded international projects (Fig. 7) [21].

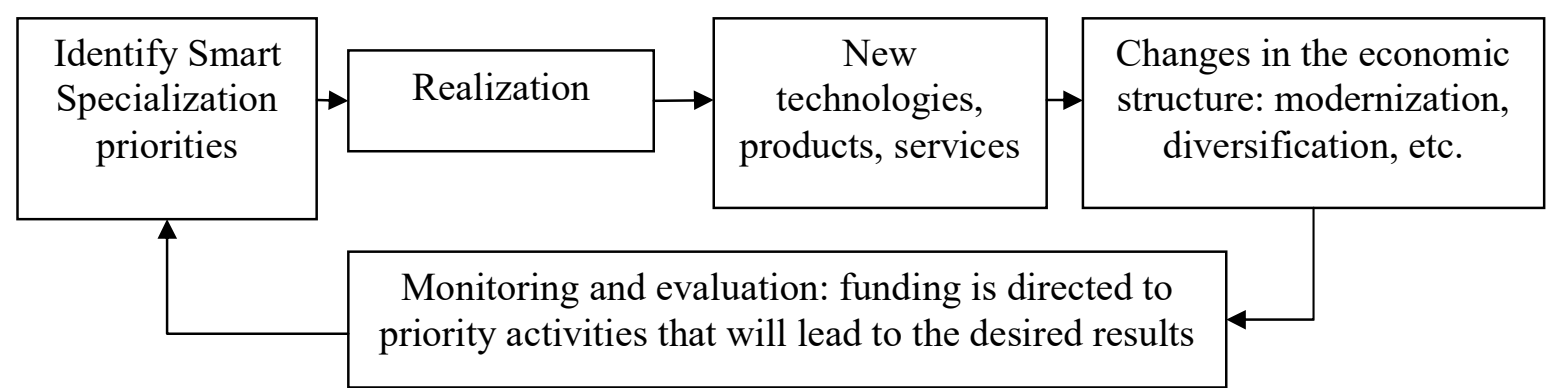

Fig. 7. Assessment of entrepreneurship in Smart Specialization

Source: formed on the basis of [22].

Analysis of the dynamics of capital investment in environmental protection by types of environmental measures by year (Table 3) allows us to define it as positive.

The dynamics of investments in the direction of biodiversity conservation and habitat have undergone the greatest changes compared to previous years.
Other measures are characterized by a wave-like movement of investment. According to the analysis of capital investments in environmental protection by region, we can see that in 2015-2018 - the largest share of investments were in Kyiv, Dnipropetrovsk and Zaporizhia regions (Table 4, Fig. 8). 
Table 3. Capital investments for environmental protection by types of environmental protection measures (2006-2018), (in actual prices, thousand UAH)

\begin{tabular}{|c|c|c|c|c|c|c|c|c|}
\hline & 푱 & 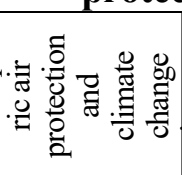 & 害离若 & 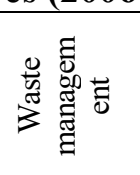 & 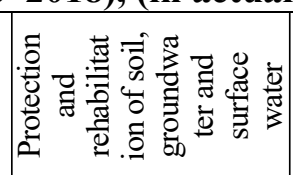 & 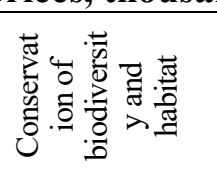 & 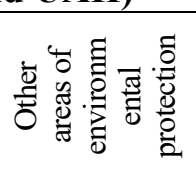 & 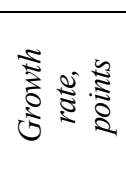 \\
\hline ஜ̊ & 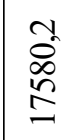 & 842,4 & 3917 & 1807,9 & 1222,8 & 40,3 & 9749,8 & $X$ \\
\hline চ্ণি & 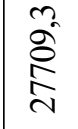 & 3021,8 & 5592,5 & 782 & 3665 & 5,3 & 14642,7 & $1,58 \uparrow$ \\
\hline$\stackrel{\infty}{\stackrel{\sim}{े}}$ & $\begin{array}{l}n \\
2 \\
\hat{\delta} \\
\dot{y}\end{array}$ & 16954,4 & 2648,9 & 4360,9 & 4094,4 & 382,3 & 18354,6 & $1,69 \uparrow$ \\
\hline ஜे & તิ̀ & 17549,5 & 571,1 & 1164,9 & 3297,6 & 26,9 & 6619,7 & $0,62 \downarrow$ \\
\hline$\stackrel{\circ}{\stackrel{\sim}{\sim}}$ & 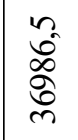 & 22604,2 & 2313,2 & 561,1 & 1958,1 & 9,6 & 9540,3 & $1,27 \uparrow$ \\
\hline $\overrightarrow{\vec{\sim}}$ & $\begin{array}{l}0 \\
\text { ते } \\
\text { त्ठ }\end{array}$ & 36333,3 & 3078,3 & 772,7 & 6434,1 & 103,2 & 15300 & $1,68 \uparrow$ \\
\hline$\stackrel{\overbrace{}}{\stackrel{\overbrace{}}{\imath}}$ & 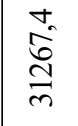 & 178,5 & 872,6 & 6150,6 & 1950 & 260,6 & 21855,1 & $0,50 \downarrow$ \\
\hline$\stackrel{m}{\stackrel{\sim}{c}}$ & $\begin{array}{l}0 \\
\stackrel{0}{\hat{n}} \\
\text { ळे }\end{array}$ & 884,3 & 3869,1 & - & 2105,9 & 3970,8 & 18507,5 & $0,94 \downarrow$ \\
\hline$\stackrel{\vec{i}}{\vec{i}}$ & ڤ్స & 648,2 & 2211,2 & 3044,9 & 420,6 & - & 995,4 & $0,25 \downarrow$ \\
\hline$\stackrel{n}{\stackrel{2}{c}}$ & n̂. & 3497,4 & 2076,7 & 2223,6 & 11,1 & - & 32724,2 & $5,54 \uparrow$ \\
\hline$\stackrel{\circ}{\stackrel{i}{*}}$ & $\begin{array}{l}\mathbb{T}^{m} \\
\mathbb{C}^{n} \\
0\end{array}$ & 413,5 & 8978,3 & 2694,9 & 3,8 & - & 51583,8 & $1,57 \uparrow$ \\
\hline $\overrightarrow{\tilde{i}}$ & $\begin{array}{l}\text { N } \\
\underset{+}{\infty} \\
\infty \\
\infty\end{array}$ & 321,9 & 10822,6 & 4875,4 & 68,8 & - & 72755,5 & $1,40 \uparrow$ \\
\hline$\stackrel{\infty}{\stackrel{i}{\sim}}$ & $\begin{array}{l}\infty \\
\stackrel{a}{0} \\
\dot{\delta}\end{array}$ & 7543,7 & 34521,5 & 2991,5 & 4 & 35889,1 & - & $0,91 \downarrow$ \\
\hline 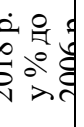 & \begin{tabular}{l}
0 \\
\multirow{2}{*}{} \\
8 \\
8
\end{tabular} & 895,50 & 881,32 & 165,47 & 0,33 & 89054,84 & 746,23 & $X$ \\
\hline
\end{tabular}

Source: formed using [22]. 
Table 4.Capital investments for environmental protection by regions (in actual prices, UAH million)

\begin{tabular}{|c|c|c|c|c|c|}
\hline Region & 2015 & 2016 & 2017 & 2018 & 2018 in \% to 2015 \\
\hline Vinnytsia region & 40,50 & 63,70 & 88,90 & 81,00 & 200,00 \\
\hline Growth rate, points & $X$ & 1,57 & 1,40 & 0,91 & $\downarrow$ \\
\hline Volyn region & 5,3 & 10,6 & 19,3 & 34,8 & 656,60 \\
\hline Growth rate, points & $X$ & 2,00 & 1,82 & 1,80 & $\uparrow$ \\
\hline Dnepropetrovsk region & 1417,9 & 1662,3 & 2628,8 & 2454,7 & 147,67 \\
\hline Growth rate, points & $X$ & 1,17 & 1,58 & 0,93 & $\uparrow$ \\
\hline Zhytomyr region & 18,0 & 16,7 & 14,6 & 8,2 & н.д. \\
\hline Growth rate, points & $X$ & 0,93 & 0,87 & 0,56 & $\uparrow$ \\
\hline Transcarpathian region & 7,8 & 5,9 & 13,8 & 45,9 & н.д. \\
\hline Growth rate, points & $X$ & 0,76 & 2,34 & 3,33 & $\uparrow$ \\
\hline Zaporizhia region & 591,5 & 1062,8 & 817,1 & 1065,3 & 180,10 \\
\hline Growth rate, points & $X$ & 1,80 & 0,77 & 1,30 & $\uparrow$ \\
\hline Ivano-Frankivsk region & 90,5 & 119,7 & 370,4 & 293,7 & 409,28 \\
\hline Growth rate, points & $X$ & 1,32 & 3,09 & 0,79 & $\downarrow$ \\
\hline Kyiv region & 4157,5 & 8313,3 & 4088,5 & 1773,6 & 98,34 \\
\hline Growth rate, points & $X$ & 2,00 & 0,49 & 0,43 & $\downarrow$ \\
\hline Kirovograd region & 6,3 & 18,5 & 14,2 & 41,4 & 657,14 \\
\hline Growth rate, points & $X$ & 2,94 & 0,77 & 2,92 & $\uparrow$ \\
\hline Lviv region & 60,4 & 104,0 & 241,4 & 284,5 & 172,19 \\
\hline Growth rate, points & $X$ & 1,72 & 2,32 & 1,18 & $\downarrow$ \\
\hline Mykolayiv region & 98,2 & 122,7 & 118,1 & 138,0 & н.Д. \\
\hline Growth rate, points & $X$ & 1,25 & 0,96 & 1,17 & $\uparrow$ \\
\hline Odesa region & 26,5 & 17,5 & 95,1 & $\mathbf{7 3 , 7}$ & 278,11 \\
\hline Growth rate, points & $X$ & 0,66 & 5,43 & 0,77 & $\downarrow$ \\
\hline Poltava region & 66,9 & 103,0 & 199,6 & 264,1 & 298,36 \\
\hline Growth rate, points & $X$ & 1,54 & 1,94 & 1,32 & $\downarrow$ \\
\hline Rivne region & 42,9 & 30,2 & 39,5 & 39,1 & н.д. \\
\hline Growth rate, points & $X$ & 0,70 & 1,31 & 0,99 & $\downarrow$ \\
\hline Sumy region & 52,5 & 48,6 & 47,1 & 22,7 & 89,71 \\
\hline Growth rate, points & $X$ & 0,93 & 0,97 & 0,48 & $\downarrow$ \\
\hline Ternopil region & 23,7 & $\mathbf{5 5 , 0}$ & 32,4 & 19,4 & н.д. \\
\hline Growth rate, points & $X$ & 2,32 & 0,59 & 0,60 & $\uparrow$ \\
\hline Kharkiv region & 62,9 & 95,2 & 340,7 & 273,1 & н.Д. \\
\hline Growth rate, points & $X$ & 1,51 & 3,58 & 0,80 & $\downarrow$ \\
\hline Kherson region & 7,9 & 2,3 & 3,2 & 15,3 & 40,51 \\
\hline Growth rate, points & $X$ & 0,29 & 1,39 & 4,78 & $\uparrow$ \\
\hline Khmelnytsky region & 19,3 & 36,7 & 35,9 & 79,4 & н.Д. \\
\hline Growth rate, points & $X$ & 1,90 & 0,98 & 2,21 & $\uparrow$ \\
\hline Cherkasy region & 54,3 & 66,8 & 22,5 & 23,1 & 41,44 \\
\hline Growth rate, points & $X$ & 1,23 & 0,34 & 1,03 & $\uparrow$ \\
\hline Chernivtsi region & 18,7 & 13,8 & 23,8 & 21,4 & 127,27 \\
\hline Growth rate, points & $X$ & 0,74 & 1,72 & 0,90 & $\downarrow$ \\
\hline Chernihiv region & 30,9 & 23,0 & $\mathbf{4 7 , 4}$ & 64,3 & н.Д. \\
\hline Growth rate, points & $X$ & 0,74 & 2,06 & 1,36 & $\downarrow$ \\
\hline Ukraine & 7675,60 & 13390,50 & 11025,60 & 10074,30 & н.Д. \\
\hline Growth rate, points & $X$ & 1,74 & 0,82 & 0,91 & $\uparrow$ \\
\hline
\end{tabular}

Source: formed using [23]. 


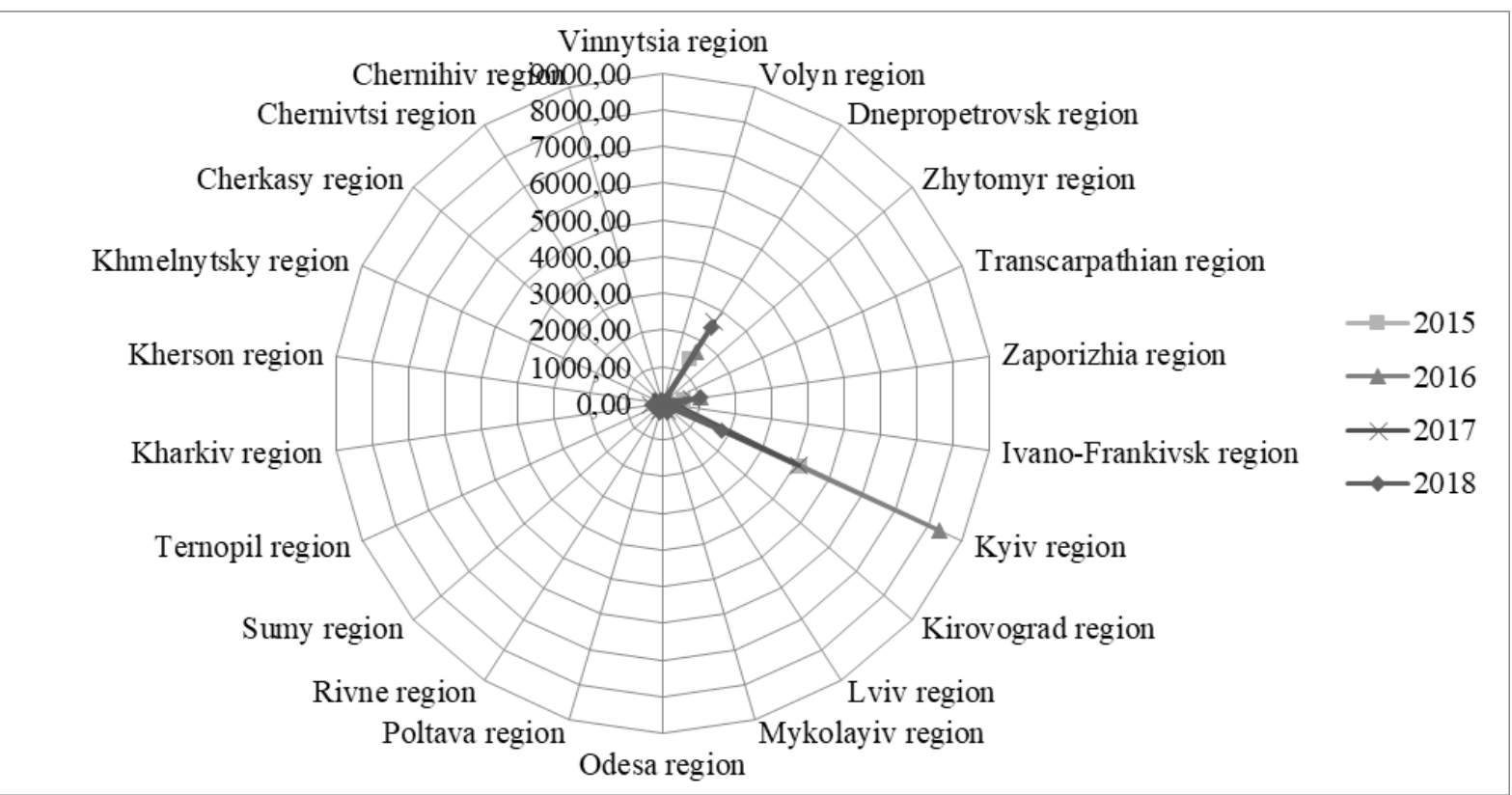

Fig. 8. Scheme of distribution of capital investments for environmental protection by Source: formed using [23]. regions, UAH mln.

Trends in increasing and decreasing investment development are defined as regional levels. Financing of environmental measures is carried out mainly from the State budget, local budgets, as well as from the own funds of enterprises, organizations and institutions. Greening is based on the transition to conservation management methods, and technically - on the greening of production technologies and nature management [24-25]. Capital investments at the expense of own means of the enterprises, the organizations, establishments on nature protection actions are resulted in table 5, fig. 9 .

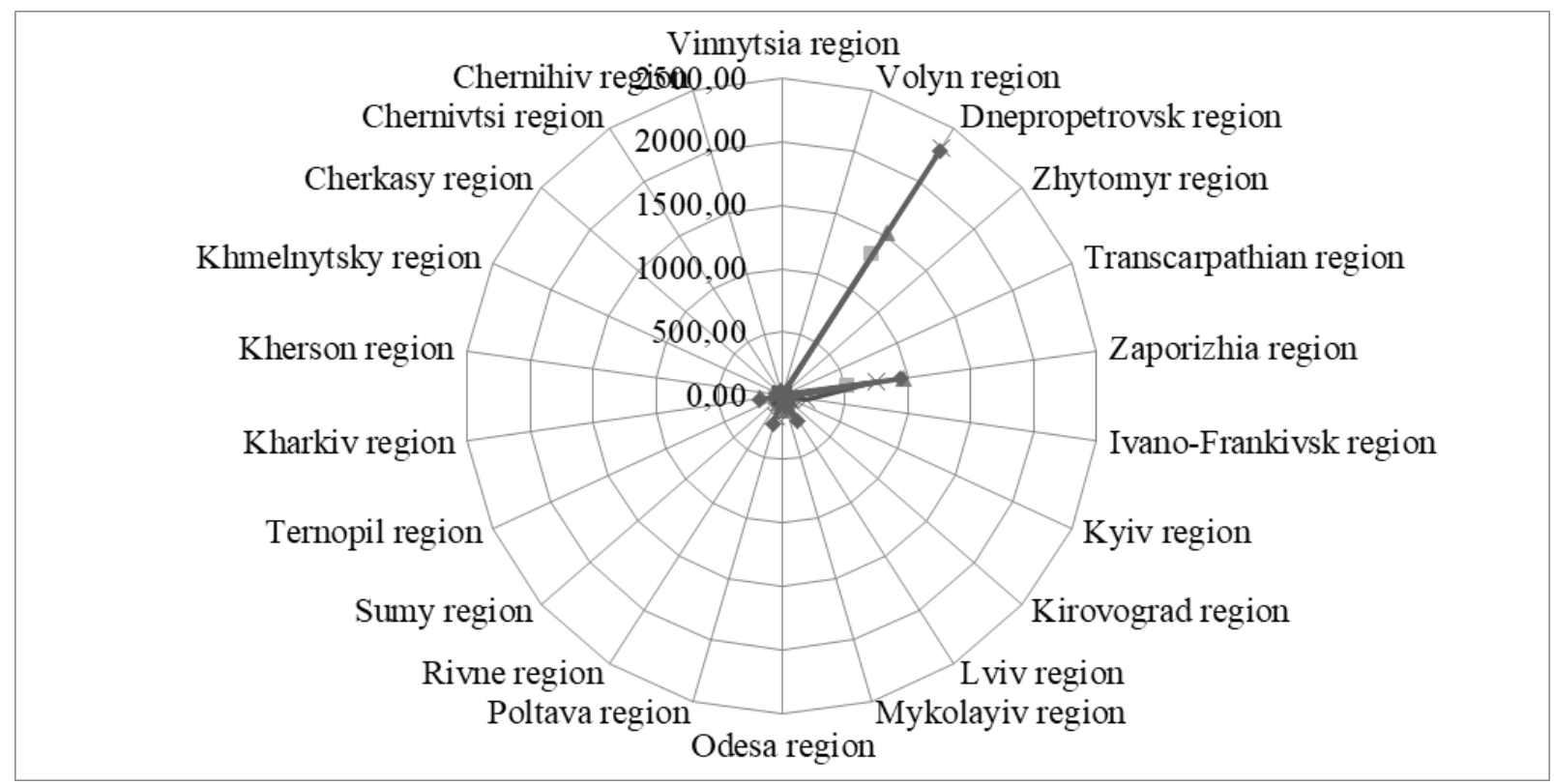

Fig. 9. Scheme of distribution of capital investments for environmental protection at the expense of own funds of enterprises, organizations, institutions by regions, UAH mln. Source: formed using [23]. 
Table 5. Capital investments for environmental protection at the expense of own funds of enterprises, organizations, institutions by regions (in actual prices, UAH million)

\begin{tabular}{|c|c|c|c|c|c|}
\hline Region & 2015 & 2016 & 2017 & 2018 & 2018 in $\%$ to 2015 \\
\hline Vinnytsia region & 7,00 & 9,50 & 6,50 & 12,70 & 181,43 \\
\hline Growth rate, points & $X$ & 1,36 & 0,68 & 1,95 & $\uparrow$ \\
\hline Volyn region & 2,30 & 8,20 & 12,30 & 10,80 & 469,57 \\
\hline Growth rate, points & $X$ & 3,57 & 1,50 & 0,88 & $\downarrow$ \\
\hline Dnepropetrovsk region & 1316,40 & 1525,30 & 2318,10 & 2293,10 & 150,34 \\
\hline Growth rate, points & $X$ & 1,16 & 1,52 & 0,99 & $\downarrow$ \\
\hline Zhytomyr region & 1,40 & 2,70 & 3,70 & 0,90 & Н.Д. \\
\hline Growth rate, points & $X$ & 1,93 & 1,37 & 0,24 & $\downarrow$ \\
\hline Transcarpathian region & 2,20 & 1,30 & 12,00 & 35,40 & н.д. \\
\hline Growth rate, points & $X$ & 0,59 & 9,23 & 2,95 & $\downarrow$ \\
\hline Zaporizhia region & 520,10 & 965,30 & 746,40 & 946,60 & 182,00 \\
\hline Growth rate, points & $X$ & 1,86 & 0,77 & 1,27 & $\uparrow$ \\
\hline Ivano-Frankivsk region & 16,00 & 18,70 & 199,50 & 80,20 & 1246,88 \\
\hline Growth rate, points & $X$ & 1,17 & 10,67 & 0,40 & $\downarrow$ \\
\hline Kyiv region & 20,10 & 63,90 & 59,20 & 24,60 & 294,53 \\
\hline Growth rate, points & $X$ & 3,18 & 0,93 & 0,42 & $\downarrow$ \\
\hline Kirovograd region & 0,40 & 0,20 & 0,10 & 0,10 & 25,00 \\
\hline Growth rate, points & $X$ & 0,50 & 0,50 & 1,00 & $\uparrow$ \\
\hline Lviv region & 57,20 & 87,70 & 141,70 & 235,20 & 153,32 \\
\hline Growth rate, points & $X$ & 1,53 & 1,62 & 1,66 & $\uparrow$ \\
\hline Mykolayiv region & 93,10 & 117,30 & 116,50 & 79,10 & н.Д. \\
\hline Growth rate, points & $X$ & 1,26 & 0,99 & 0,68 & $\downarrow$ \\
\hline Odesa region & 19,10 & 16,10 & 21,90 & 21,30 & 111,52 \\
\hline Growth rate, points & $\mathrm{X}$ & 0,84 & 1,36 & 0,97 & $\downarrow$ \\
\hline Poltava region & 54,70 & 55,20 & 169,40 & 236,20 & 309,69 \\
\hline Growth rate, points & $X$ & 1,01 & 3,07 & 1,39 & $\downarrow$ \\
\hline Rivne region & 27,50 & 12,10 & 2,30 & 7,00 & Н.Д. \\
\hline Growth rate, points & $X$ & 0,44 & 0,19 & 3,04 & $\uparrow$ \\
\hline Sumy region & 27,80 & 22,60 & 18,20 & 11,30 & 65,47 \\
\hline Growth rate, points & $X$ & 0,81 & 0,81 & 0,62 & $\downarrow$ \\
\hline Ternopil region & 3,10 & 22,10 & 9,60 & 3,50 & н.Д. \\
\hline Growth rate, points & $X$ & 7,13 & 0,43 & 0,36 & $\downarrow$ \\
\hline Kharkiv region & 42,60 & 45,10 & 119,80 & 178,90 & н.Д. \\
\hline Growth rate, points & $X$ & 1,06 & 2,66 & 1,49 & $\downarrow$ \\
\hline Kherson region & 1,10 & 1,20 & 1,90 & 11,80 & 172,73 \\
\hline Growth rate, points & $X$ & 1,09 & 1,58 & 6,21 & $\uparrow$ \\
\hline Khmelnytsky region & 4,40 & 23,90 & 8,80 & 48,70 & Н.Д. \\
\hline Growth rate, points & $X$ & 5,43 & 0,37 & 5,53 & $\uparrow$ \\
\hline Cherkasy region & 24,80 & 19,20 & 5,70 & 20,30 & 22,98 \\
\hline Growth rate, points & $X$ & 0,77 & 0,30 & 3,56 & $\uparrow$ \\
\hline Chernivtsi region & 1,30 & 1,40 & 0,90 & 0,50 & 69,23 \\
\hline Growth rate, points & $X$ & 1,08 & 0,64 & 0,56 & $\downarrow$ \\
\hline Chernihiv region & 3,30 & 4,50 & 19,40 & 38,50 & Н.Д. \\
\hline Growth rate, points & $X$ & 1,36 & 4,31 & 1,98 & $\downarrow$ \\
\hline Ukraine & 2692,30 & 3896,90 & 5132,10 & 6844,20 & н.Д. \\
\hline Growth rate, points & $X$ & 1,45 & 1,32 & 1,33 & $\uparrow$ \\
\hline
\end{tabular}
Source: formed using [23].

The distribution of capital investments in environmental protection at the expense of own funds of enterprises, organizations, institutions is characterized by the greatest dynamics in Dnipropetrovsk and Zaporizhia regions. Trends in investment at the expense of own funds of enterprises, organizations, institutions are characterized by declining dynamics in most regions of Ukraine (Table 6). The dynamics of the implementation of environmental measures and the solution of environmental problems by region is presented in Fig. 10, 11. 


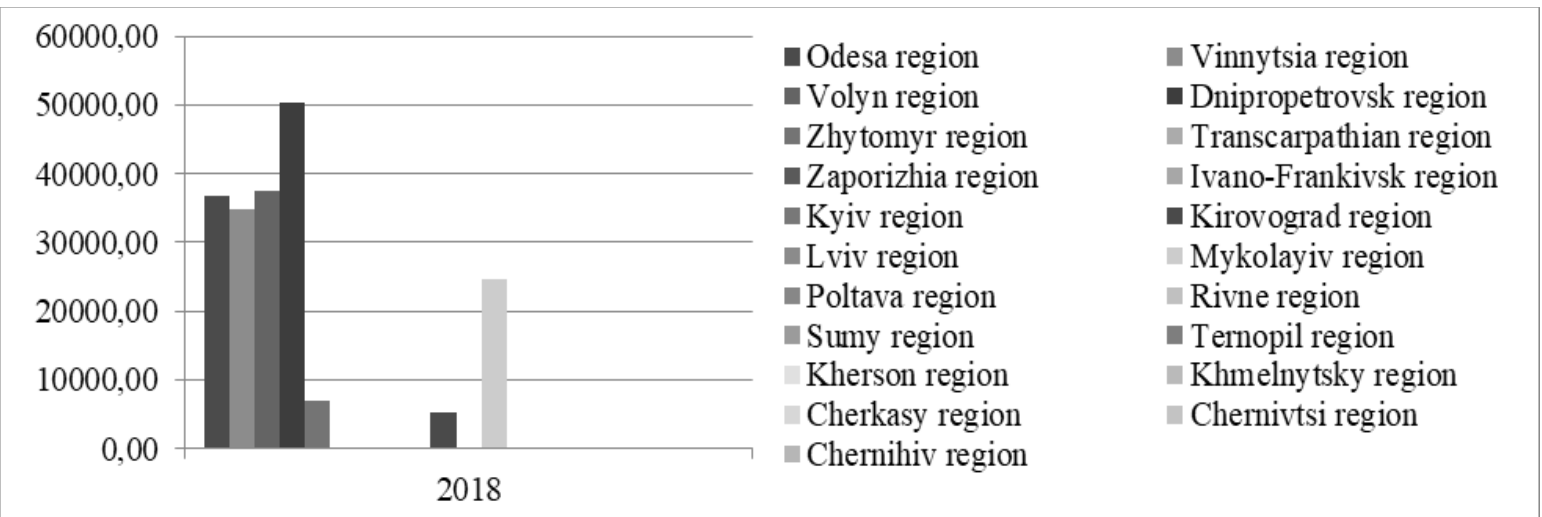

Fig. 10. Solving environmental problems in 2018, thousand UAH

Source: formed using [25].

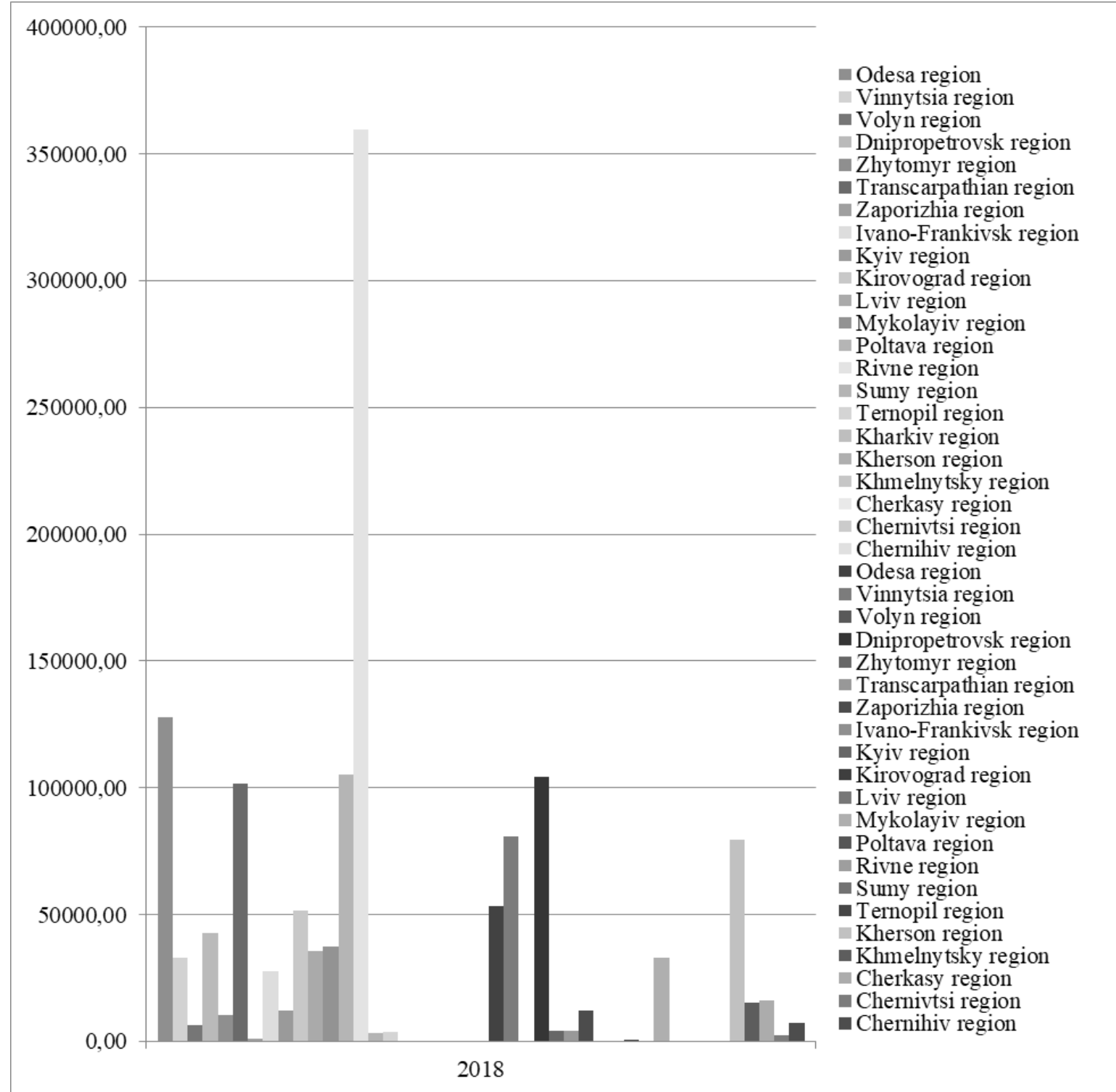

Fig. 11. Implementation of environmental measures in 2018, thousand UAH

Source: formed using [25]. 
Solving environmental problems is characterized by the best results in Dnipropetrovsk region. From the figures you can see that in Rivne, Vinnytsia and Odesa regions the indicators of financing the implementation of environmental measures have reached the greatest importance. In Kyiv, on the other hand, large-scale financing of greening and solving environmental problems is being carried out. According to statistical observations, it can be recommended that Ukraine's investment and innovation policy be based on: meso-level strategy aimed at strengthening inclusive and sustainable development through synergies between neighboring regions; research and innovation strategies based on both the analysis of the strengths and potential of the local economy and the process of starting a business, taking into account the approach of intellectual specialization (RIS3), which defines strategic areas of development.

After all, the dynamics of growth of investment development through individual development and through state and local budgets has a difference in its development. This requires the introduction of a mechanism for managing the concentration of financial resources of executive bodies, the area of responsibility and policy of which is characterized by territorial orientation and influence on the development of individual regions, districts and cities.

Conclusions. Summarizing all the above, we note that the analysis of economic activity and investment potential of environmental protection of the regions of Ukraine allowed us to determine that in most regions the production of gross regional product is a strong point of development.
The volume of investments actually disbursed in the reporting period at the expense of the state budget of Ukraine and local budgets for environmental protection is characterized by increasing dynamics, but is generally not a strong point of regional development.

Volumes of investments disbursed at the expense of own funds of enterprises of all forms of ownership - funds received by the enterprise as a result of ordinary activities, as well as depreciation of tangible and intangible non-current assets accrued during the reporting period are reflected in Dnipropetrovsk and Zaporozhye regions.

The scientific and innovative potential of the regions of Ukraine is the strongest component of the development of smart Specialization. Only in a few areas does it need significant support and cooperation. Employment in the field of nature management is characterized by an almost equal distribution among the regions. The location of higher education institutions is the weakest component of the group, as is the concentration of students (talents).

Implementation of the Smart Specialization Strategy, which will provide a combination of the above components will provide an opportunity to determine the approach to the formation and implementation of state regional policy. The search for a dominant position of the regions is aimed at preventing the growth of disparities that hinder the development of regions and should be ensured through a coherent policy to stimulate the development of "growth points" and support economically less developed and depressed areas.

\section{ACKNOWLEDGEMENT}

The research was performed within the Research work "Dominants of investment and innovation policy of nature management of the national economy "budget program" Support for the development of priority areas of research " (Code of the budget program 6541230). 


\section{REFERENCES}

1. Bakushevich, I., Goshchinskaia, D. \& Martyniak, I., (2019). Applied aspects of European integration development of the regions of Ukraine. Socio-economic problems and the state, 2 (21), 235-245. [in Ukranian].

2. Decentralization (2019). Regional Development Strategies 2021-2027: what should the regions do this year to reach a qualitatively new level of strategic planning. Retrieved from: https://decentralization.gov.ua/news/10591 [in Ukranian].

3. Odessaizbirkom (2018). Odessa region was chosen to participate in the EU project "SMART-specialization". Retrieved from: https://izbirkom.org.ua/news/ekonomika9/2018/odesskuiu-oblast-vybrani-dlia-uchastiia-v-proekte-evrosoiuza-smart-spetsializatsiia

4. Foray, D., Goddard, J., Beldarrain, X.G., Landabaso, M., McCann, P., Morgan, K., Nauwelaers, C. \& Ortega-Argilés, R. (2012). Guide to Research and Innovation Strategies for Smart Specializations (RIS 3), European Commission.

5. Richardson, K. (2014). Smart Specialization: What does it mean in practice for universities? Retrieved from: https://youtu.be/a_sGcbmKe1g.

6. Ortega A.R., McCann, P., Perianez-Forte, I., Cervantes, M., Larosse, J. \& Sanchez, L. (2013). Innovation-driven growth in regions: the role of smart specialization. OECD Science, Technology and Industry Policy Papers, 12. Paris: OECD / ODCE.

7. Sugimoto, C.R., Robinson-Garcia, N. \& Costas, R. (2016). Towards a Global Scientific Brain: Indicators of Researcher Mobility using co-affiliation Data. Ghent, Belgium.

8. Bakhshi, H. \& Mateos-Garcia, J. (2016). New Data for Innovation Policy. Ghent, Belgium.

9. Delaney, K. \& Osborne, L. (2013). Public sector horizon scanning-stocktake of the Australasian joint agencies scanning network. Journal of Futures Studies, 17 (4), 55-70.

10. Patytska, H.O. (2019). Smart Specialization Strategy in the Context of Ensuring the Competitiveness of the Region: A Theoretical Aspect. Efficient economy, 11. https://doi.org/10.32702 / 2307-2105-2019.11.53.

11. The S3 Platform Peer Review Methodology (2014). JRS Technical reports. S3 Working papers, No. 02/2014, Joint Research Center, Seville, Spain.

12. Innovation and specialization regional in Latin America (2017). JRS Technical reports, European Commission.

13. Cornell University, INSEAD, and WIPO. (2018). The Global Innovation Index 20102018. Retrieved from: http://www.globalinnovationindex.org.

14. On priority areas of innovation in Ukraine: Law of Ukraine of September 8, 2011 No. 3715-VI. Official Gazette of Ukraine dated 14.10.2011, No.77, p. 14, Article 2841, act $58478 / 2011$.

15. State Statistics Service of Ukraine (2019). Scientific and innovative activities in Ukraine in 2015. Retrieved from: http://www.ukrstat.gov.ua.

16. State Statistics Service of Ukraine (2019). Higher educational institutions of I-IV levels of accreditation. Retrieved from: http://www.ukrstat.gov.ua.

17. State Statistics Service of Ukraine (2019). Number of students at the beginning of the school year. Retrieved from: http://www.ukrstat.gov.ua.

18. State Statistics Service of Ukraine (2020). Economic activity of the population of Ukraine 2016-2018: statistical collection. Retrieved from: http://www.ukrstat.gov.ua.

19. Ministry of Regional Development, Construction and Housing of Ukraine (2019). On amendments to the Procedure for evaluation of regional development projects that can be implemented at the expense of the state budget received from the European Union: Order of 17.07.2019 No. 165.. Official Gazette of Ukraine dated August 30, 2019, No. 66, p. 343, Article 2327 , act code $95593 / 2019$.

20. State Statistics Service of Ukraine (2019). Gross regional product in 2017. Statistical collection. Kyiv. 
21. Foray, D., Goddard, J., Beldarrain, XG, Landabaso, M., McCann, P., Morgan, K., Nauwelaers, C. \& Ortega-Argilés, R. (2012). Guide to Research and Innovation Strategies for Smart Specializations (RIS 3), European Commission.

22. State Statistics Service of Ukraine (2019). Capital investments in environmental protection. Retrieved from: http://www.ukrstat.gov.ua.

23. State Statistics Service of Ukraine (2019). Environment of Ukraine for 2018. Retrieved from: http://www.ukrstat.gov.ua.

24. Kostetska, K., Khumarova, N., Umanska, Y., Shmygol, N., \& Koval, V. (2020). Institutional qualities of inclusive environmental management in sustainable economic development. Management Systems in Production Engineering, 28 (2), 15-22. https://doi.org/10.2478/mspe-2020-0003.

25. Ministry of Energy and Environmental Protection (2020). Regional report on the state of the environment in 2015-2018. Retrieved from: https://menr.gov.ua. 